\title{
Pendekatan Technology Acceptance Model (TAM) dan Importance Performance Analysis (IPA) untuk Menganalisa Kemudahan dan Kegunaan Aplikasi Solfina Pada PT. SKK di Jakarta
}

\author{
Nanang Subandi ${ }^{1}$, Baginda Oloan Lubis ${ }^{* 2)}$, Budi Santoso ${ }^{3)}$ \\ ${ }^{1)}$ Sistem Informasi, STMIK Nusa Mandiri \\ ${ }^{2}$ Sistem Informasi, Fakultas Teknik dan Informatika, Universitas Bina Sarana Informatika \\ ${ }^{3)}$ Teknologi Komputer, Fakultas Teknik dan Informatika, Universitas Bina Sarana Informatika \\ ${ }^{*}$ Correspondence Author: baginda.bio@ bsi.ac.id, DKI Jakarta, Indonesia \\ DOI: https://doi.org/10.37012/jtik.v7i1.504
}

\begin{abstract}
Abstrak
Dalam bidang bisnis aplikasi yang sering digunakan adalah aplikasi Solfina yang sangat membantu dalam kegiatan sehari-hari dan memudahkan pekerjaan sehingga pekerjaan lebih efisien dan efektif. Di masa sekarang ini setiap perusahaan dituntut agar dapat menyajikan informasi secara cepat, mudah, tepat dan akurat. Penggunaan aplikasi Solfina menjadi sangat penting untuk mendukung proses kegiatan bisnis pekerjaan dalam menghadapi situasi dan kondisi yang sedang berkembang dengan cepat. Aplikasi Solfina pada umumnya sudah di gunakan oleh beberapa perusahaan untuk mendukung proses kerja setiap hari. Pada PT. SKK semua karyawan diwajibkan menggunakan aplikasi Solfina. Dengan penggunaan aplikasi Solfina di lingkungan perusahaan PT. SKK, karyawan terbantu mempermudah pelaksanaan tugas dan pekerjaannya dalam mengolah data purchase order, data sales order sampai dengan pembuatan laporan. Berdasarkan latar belakang tersebut maka dapat ditarik beberapa permasalahan yang timbul dari penggunaan aplikasi Solfina diantaranya bagaimana hasil evaluasi aplikasi Solfina pada PT. SKK dengan pendekatan TAM dan IPA dan bagaimana tingkat kemudahan dan kegunaan aplikasi Solfina pada PT. SKK, sehingga dapat diusulkan ke pengembang aplikasi bagian mana saja yang harus diperbaiki dan dikembangkan. Hasil dari penelitian ini menjelaskan bahwa secara umum aplikasi Solfina harus diperbaikai ini menunjukkan bahwa hipotesa H0 diterima dan $\mathrm{H} 1$ ditolak.
\end{abstract}

Kata kunci: Aplikasi Solfina, Technology Acceptance Model, Importance Performance Analysis

\begin{abstract}
In the business field, the application which is oftenly used is the Solfina application. This application is very helpful in daily activities and is able to make work easier, more efficient, and effective. Nowadays, every company is required to be able to present information quickly, easily, precisely and accurately. The use of the Solfina application is very important to support the process of work business activities in facing situations and conditions that are developing rapidly. The Solfina application in general has been used by several companies to support daily work processes. At PT. SKK, all employees are required to use the Solfina application. With the use of the Solfina application in the PT. SKK, it enables employees to make it easier to carry out their duties and work in processing purchase order data, sales order data, and preparing reports. Based on this background, several problems can be drawn that arise from the use of the Solfina application; how the evaluation of the use of Solfina application at PT. SKK by using TAM and IPA approaches is, how easy and useful the Solfina application is at PT. SKK so that it can be implemented to application developers which parts should be repaired and developed. The results of this study explain that in general, the Solfina application must be furthermore improved. It shows that the hypothesis HO is accepted and HI is rejected.
\end{abstract}

Keywords: Solfina Application, Technology Acceptance Model, Importance Performance Analysis 


\section{PENDAHULUAN}

Aplikasi Solfina pada umumnya sudah di gunakan oleh perusahaan untuk mendukung proses kerja setiap harinya demikian juga pada PT. SKK yang berlokasi di Jl. HR. Rasuna Said Jakarta. Semua karyawan diwajibkan menggunakan aplikasi Solfina. Dengan penggunaan aplikasi Solfina pada perusahaan PT. SKK, karyawan terbantu dalam mempermudah pelaksanaan tugas dan pekerjaannya sehari-hari. Pemanfaatan penggunaan aplikasi Solfina diharapkan dapat mengubah cara kerja karyawan dan menimbulkan budaya kerja yang lebih baik. Saat ini para pelaku usaha makin menyadari tentang pentingnya penerapan sistem informasi dalam kegiatan usahanya. Banyak manfaat positif yang didapat dari suatu aplikasi, maka penerapannya pun dilakukan dengan harapan untuk menunjang operasional usahanya.

Selama ini penggunaan aplikasi Solfina pada PT. SKK belum ada yang menganalisa apakah aplikasi Solfina ini benar menunjang pekerjaan karyawan, apakah kualitas dari aplikasi ini baik sehingga mempercepat pekerjaan karyawan. Pada kesempatan ini dilakukan penelitian tingkat kemudahan dan kegunaan dari aplikasi Solfina ini.

Usability berasal dari kata usable yang secara umum berarti dapat digunakan dengan baik. Sesuatu dapat dikatakan berguna dengan baik apabila kegagalan dalam penggunaannya dapat dihilangkan atau diminimalkan serta memberi manfaat dan kepuasan kepada pengguna. Rubin dan Chisnell dalam (Lubis \& Salim, 2016).

Penelitian yang telah dilakukan sebelumnya menjelaskan bahwa pengukuran atas kesuksesan penerapan aplikasi pada suatu lembaga atau organisasi akan mengetahui kelebihan dan kekurangan aplikasi tersebut yang akan berguna untuk pengembangan. (Agustina \& Sutinah, 2019).

Untuk mengetahui faktor-faktor yang dapat mempengaruhi penerimaan pengguna dalam transaksi online pada Shopee di kalangan mahasiswa dapat dilakukan penelitian dengan menggunakan model penerimaan teknologi atau Technology Acceptance Model (TAM), model ini menyebutkan bahwa pengguna akan lebih cenderung menggunakan sistem apabila sistem tersebut mudah digunakan dan bermanfaat bagi penggunanya. (Nurfiyah, Mayangky, Hadianti, \& Riana, 2019)

Penelitian berikutnya yang sudah publikasi menjelaskan bahwa dengan penggunaan aplikasi LOS di lingkungan perusahaan, analis kredit merasa terbantu mempermudah pelaksanaan tugas dan pekerjaannya dalam mengolah data, menghitung simulasi kredit dan merekam data dari calon nasabah. (Lubis, Santoso, Aji, Haidir, \& Salim, 2019) 
Berdasarkan penelitian yang telah dilakukan sebelumnya penelitian ini bertujuan untuk menganalisa aplikasi Solfina pada PT. SKK hingga dapat mengetahui kelebihan dan kekurangannya. Selain itu dari hasil penelitian nanti akan diketahui bagian mana dari aplikasi Solfina yang harus diperbaiki dan dikembangkan.

\section{METODE}

\section{A. Komponen dan Proses Penelitian}

Penelitian yang menganalisa kemudahan dan kegunaan aplikasi Solfina pada PT. SKK ini menggunakan penelitian kuantitatif dengan komponen dan proses penelitian sebagai berikut:

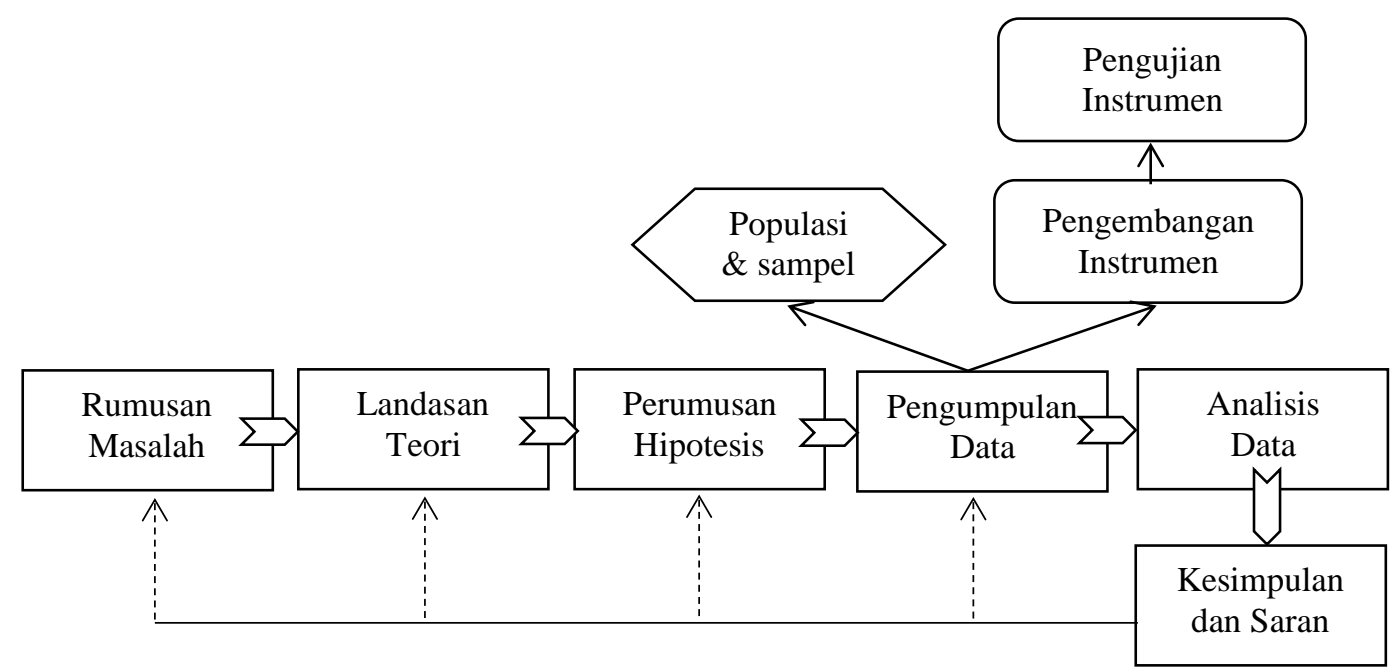

Sumber : (Sugiyono, 2016)

Gambar 1. Komponen dan Proses Penelitian Kuantitatif

Dari gambar 1 di atas dapat dijelaskan kompunen dan proses penelitian dijelaskan secara umum yaitu:

1. Rumusan Masalah

Manentukan permasalahan yang ada pada aplikasi Solfina sehingga ditetapkan untuk mengevaluasi aplikasi Solfina dengan pendekatan model TAM dan IPA difokuskan kepada analisa kemudahan dan kegunaan di PT. SKK Jakarta

2. Landasan Teori

Kajian teori dalam penelitian ini merujuk literatur artikel ilmiah, buku dan informasi yang didapat dari internet yang dapat dipercaya yang disesuaikan dengan permasalahan yang akan dibahas pada penelitian ini.

3. Perumusan Hipotesis

Mengemukakan pernyataan H0 yaitu diduga pengguna aplikasi Solfina pada PT. SKK belum merasa puas terhadap kegunaan dan kemudahan, dan $\mathrm{H} 1$ diduga pengguna aplikasi Solfina pada PT. SKK sudah merasa puas terhadap kegunaan dan kemudahan. 
4. Pengumpulan Data

a. Populasi dan Sampel

Tahap ini dilakukan pencarian sampel berdasarkan populasi yang sudah ditentukan terlebih dahulu. Populasi merupakan sekumpulan individu yang memiliki karakteristik khas yang menjadi perhatian dalam lingkup yang ingin diteliti. Banyaknya anggota suatu populasi disebut sebagai ukuran populasi. (Sugiarto, 2017). Populasi pada penelitian ini adalah karyawan PT. SKK yang menggunakan aplikasi Solfina dalam pekerjaan sehari-hari.

Sampel adalah sebagian dari jumlah dan karakteristik yang dimiliki oleh populasi. Karena populasi yang besar peneliti tidak mempelajari semua yang ada pada populasi karena keterbatasan pada waktu dan juga tenaga. Oleh sebab itu peneliti menggunakan sampel yang diperoleh dari populasi yang benar-benar representatif atau sampel yang mencerminkan secara jelas dari sebuah populasi.

Untuk pengambilan sample dalam penelitian ini menggunakan non probability sampling dan jenis yang digunakan adalah Convinience Sampling dimana semua pengguna dalam hal ini karyawan pada PT. SKK dijadikan sampel sebanyak 15 orang. (Sugiarto, 2017)

b. Pengembangan Instrumen

Tahapan ini adalah penentuan instrumen penelitian yaitu dengan menggunakan kuesioner. Penyusunan kuesioner ini terbagi menjadi dua bagian yaitu identitas sumber data dan kuantitatif. Data kualitatif menggunakan dua skala yaitu skala yang digunakan untuk tingkat kepentingan (importance) dan skala yang digunakan untuk tingkat kinerja (performance).

c. Pengujian Instrumen

Tahap pengujian instrumen dilakukan dengan pengujian prasyarat dimana pengujian yang dilakukan untuk menguji tingkat validitas dan reliabitas dari instrumen yang digunakan pada saat proses pengumpulan data.

5. Analisis Data

Data hasil penelitian kemudian dianalisa dengan tools dan teori yang sudah ada yaitu dengan analisis Importance Performance Analysis (IPA). Dengan analisa data menggunakan pendekatan Importance Performance Analysis (IPA) akan ditemukan solusi untuk pengembangan lebih lanjut aplikasi yang dibahas dalam penelitian ini.

6. Kesimpulan dan Saran 
Kesimpulan diambil berdasarkan analisa data dan diperiksa apakah sesuai dengan maksud dan tujuan penelitian dan saran peneliti dipaparkan untuk penelitian selanjutnya.

\section{B. Aplikasi Solfina}

Solfina Payroll adalah salah satu masterpiece aplikasi kantor yang diperuntukkan sebagai solusi utama penggajian dan personalia bagi perusahaan di Indonesia. Solfina Payroll dapat mengatasi persoalan yang sering ditemui dalam departemen HRD dan Finance termasuk laporan personalia, proses penggajian, penghitungan dan pelaporan PPh 21. (Solsistem, 2021).

\section{Pengertian Aplikasi}

Dalam penelitian yang dilakukan di tahun 2018 menjelaskan bahwa "Pengertian aplikasi secara umum adalah alat terapan yang difungsikan secara khusus dan terpadu sesuai kemampuan yang dimilikinya aplikasi merupakan suatu perangkat komputer yang siap pakai bagi user". (Siregar, Siregar, \& Melani, 2018). Menurut Santoso dalam penelitiannya menjelaskan bahwa "Aplikasi adalah suatu kelompok file (form, class, report) yang bertujuan untuk melakukan aktivitas tertentu yang saling terkait, misalnya aplikasi payroll, aplikasi fixed asset, dll”. (Abdurahman, Hasan \& Riswaya, 2014). Menurut Rachmad Hakim $\mathrm{S}$ dalam penelitiannya menjelaskan bahwa "Aplikasi adalah perangkat lunak yang digunakan untuk tujuan tertentu, seperti mengolah dokumen, mengatur Windows \&, permainan (game), dan sebagainya.” (Abdurahman, Hasan \& Riswaya, 2014)

\section{Technology Acceptance Model (TAM)}

Model TAM berasal dari teori psikologis untuk menjelaskan perilaku pengguna teknologi informasi yang berlandaskan pada kepercayaan (beliefs), sikap (attitude), minat (intention) dan hubungan perilaku pengguna (User Behavior Relatioship). Tujuan model ini adalah untuk dapat menjelaskan faktor-faktor utama dari perilaku pengguna teknologi informasi terhadap penerimaan penggunaan teknologi informasi itu sendiri. Model ini akan menggambarkan bahwa penggunaan SI akan dipengaruhi oleh variabel kemanfaatan (Usefullness) dan variabel kemudahan pemakaian (Ease of Use), dimana keduanya memiliki determinan yang tinggi dan validitas yang telah teruji secara empiris. Davis dalam (Widianto, 2015).

Dalam penelitian (Fatmawati, 2015) awalnya Davis menggunakan sebanyak 14 ukuran (initial scale items) sebagai indikator yang ada dalam Perceived Usefullnes dan Perceived Ease of Use. Selanjutnya memulai dengan kajian ke-1 yang merupakan uji coba awal/studi 
pra test yang di lakukan untuk mengetahui reliabilitas maupun validitas dan memperoleh hasil berupa 10 macam indikator. Mengenai apa saja indikatornya dijelaskan seperti pada gambar 2 berikut:

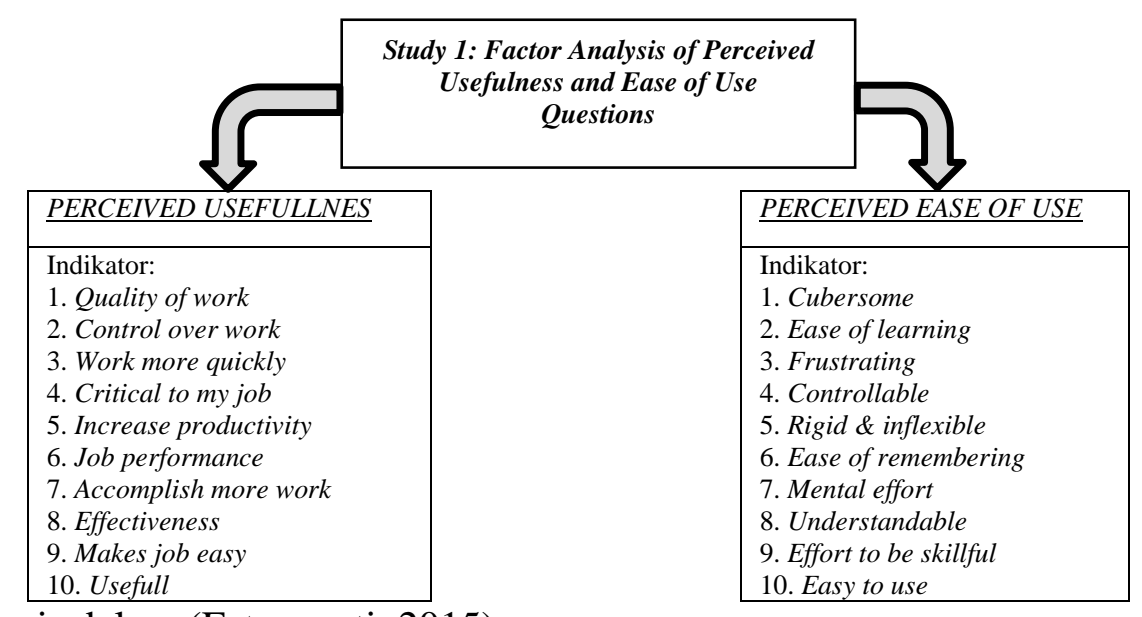

Sumber: Davis dalam (Fatmawati, 2015)

Gambar 2. Factor Analysis of TAM Questions

Selanjutnya pada kajian ke-2, Davis melakukan uji coba prototype atau model dengan memperkecil indikator sehingga menjadi lebih baik dan lebih praktis. Analisis yang dilakukan waktu itu dengan menghitung Korelasi (antara Perceived Usefulness, Perceived Ease of Use dan Self Reported System Usage) maupun Analisis Regresi (Effect of Perceived Usefulness dan Perceived Ease of Use on Self-Reported Usage)

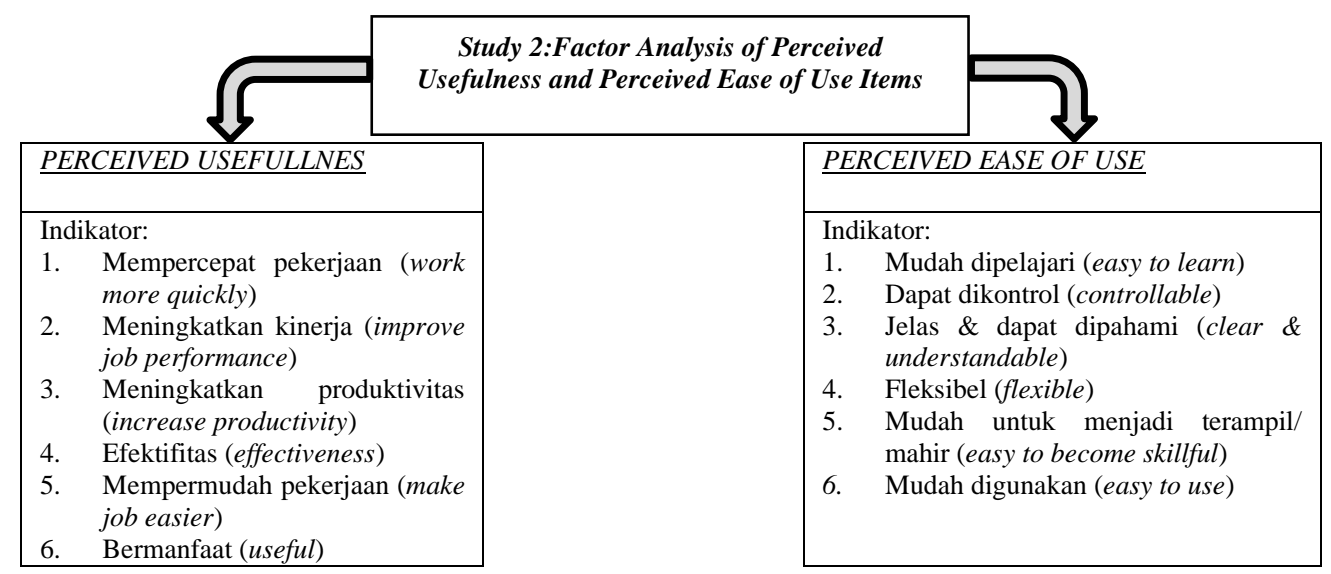

Sumber: Davis dalam (Fatmawati, 2015)

\section{Gambar 3. Factor Analysis of TAM Items}

Kedua faktor ini dapat menjelaskan aspek keperilakuan pengguna. Kesimpulannya adalah model TAM dapat menjelaskan bahwa persepsi pengguna akan menentukan sikapnya dalam kemanfaatan penggunaan TI. Model ini secara lebih jelas menggambarkan bahwa penerimaan penggunaan TI dipengaruhi oleh kemanfaatan (usefulness) dan kemudahan penggunaan (ease of use).

Variabel-variabel yang digunakan dalam TAM menurut Davis dalam (Mahendra, 2016): 

a. Persepsi kegunaan
b. Persepsi kemudahan penggunaan
c. Sikap terhadap penggunaan
d. Minat perilaku untuk menggunakan
e. Penggunaan sistem sesungguhnya

\section{E. Instrumen Penelitian}

Dalam penelitian ini instrumen yang digunakan adalah angket/kuesioner dengan membuat pertanyaan yang diikuti oleh kolom-kolom yang menunjukkan tingkatan atau dengan istilah lain rating scala (skala bertingkat) yang disampaikan kepada sampel dari populasi dalam hal ini adalah karyawan pada PT. SKK yang menggunakan aplikasi Solfina. Disini diperlukan dua jenis data dimana data tingkat kepentingan (importance) dan tingkat kinerja (performance) dari aplikasi Solfina. Kisi-kisi instrumen penelitian sebagai berikut:

Tabel 1. Kisi-Kisi Instrumen Penelitian

\begin{tabular}{llll}
\hline No & Variabel Penelitian & & \multicolumn{1}{c}{ Dimensi (Indikator) } \\
\hline 1. & Persepsi & 1. & Aplikasi Solfina mudah dipelajari. \\
& Kemudahan & 2. Aplikasi Solfina mudah dikendalikan. \\
& Penggunaan & 3. & Aplikasi Solfina jelas dan mudah dipahami. \\
& (Perceived Ease of & 4. & Aplikasi Solfina fleksibel. \\
& Use & 5. & Mudah untuk terampil dalam menggunakan aplikasi Solfina. \\
& 6. & Aplikasi Solfina mudah diakses. \\
\hline 2. & Persepsi Kegunaan & 1. & Menggunakan aplikasi Solfina membuat pekerjaan lebih cepat. \\
& Usefulness) & 2. & Menggunakan aplikasi Solfina meningkatkan prestasi kerja. \\
& & 3. & Menggunakan aplikasi Solfina meningkatkan produktivitas. \\
& & 5. & Menggunakan aplikasi Solfina meningkatkan efektivitas. \\
& & 6. Aplikgani Solfina berguna dalam bekerja. \\
\hline
\end{tabular}

Sumber : Sugiyono dalam (Mahendra, 2016)

Variabel yang digunakan pada penelitian ini adalah variabel yang tidak dapat diukur secara langsung (variabel laten) yaitu:

a. Variabel (X1) yaitu: Persepsi Kemudahan Penggunaan (Perceived Ease of Use) Tingkat Kepentingan (Importance).

b. Variabel (X2) yaitu: Persepsi Kegunaan (Perceived Usefulness) Tingkat Kepentingan (Importance).

c. Variabel (Y1) yaitu: Persepsi Kemudahan Penggunaan (Perceived Ease of Use) Tingkat Kinerja (Performance).

d. Variabel (Y2) yaitu: Persepsi Kegunaan (Perceived Usefulness) Tingkat Kinerja (Performance).

\section{F. Pengujian Prasyarat}

Pengujian prasyarat adalah pengujian yang dilakukan untuk menguji tingkat validitas dan reliabitas dari instrumen yang akan digunakan pada saat proses pengumpulan data. 
Validitas dan reliabilitas instrumen penelitian merupakan syarat mutlak untuk mendapatkan data yang sahih dan dapat dipercaya, yang pada akhirnya akan berpengaruh terhadap kualitas hasil penelitian. (Mahendra, 2016).

\section{Uji Validitas}

Validitas adalah indeks yang menunjukkan sejauh mana suatu alat ukur betul-betul mengukur apa yang perlu diukur. Sehingga dengan demikian, uji validitas dilakukan untuk menguji tingkat ketepatan dan kecermatan suatu instrumen penelitian dalam melakukan fungsinya untuk mendapatkan data yang tepat dan akurat. Dalam penelitian ini, teknik yang digunakan untuk mengetahui derajat kevalidan instrumen adalah dengan menggunakan teknik korelasi product moment yang dikemukakan oleh Karl Pearson dengan menggunakan rumus sebagai berikut. Morissan dalam (Mahendra, 2016)

$$
r_{x y}=\frac{N \sum x y-\sum x \sum y}{\sqrt{\left\{N \sum x^{2}-\left(\sum x^{2}\right)\right\}\left\{N \sum y^{2}-\left(\sum y^{2}\right)\right\}}}
$$

Sumber: Morissan dalam (Mahendra, 2016)

Uji statistik korelasi product moment dilakukan dengan cara mengolerasikan antara skor yang diperoleh pada masing-masing item pertanyaan dan skor totalnya. Skor total diperoleh dari hasil penjumlahan semua skor item. Skor masing-masing item haruslah berkorelasi secara signifikan dengan skor totalnya.

Dasar pengambilan keputusan dalam uji korelasi product moment, adalah:

a. Apabila nilai $r$ hitung lebih besar daripada nilai $r$ tabel, maka item pertanyaan berkorelasi signifikan terhadap skor total (dinyatakan valid).

b. Apabila nilai $r$ hitung lebih kecil daripada nilai $r$ tabel, maka item pertanyaan tidak berkorelasi signifikan terhadap skor total (dinyatakan tidak valid).

\section{Uji Reliabilitas}

Uji reliabilitas terhadap instrumen penelitian dilakukan untuk menguji derajat konsistensi dan stabilitas instrumen dalam interval waktu tertentu, sehingga apabila instrumen tersebut digunakan beberapa kali untuk mengukur objek yang sama akan menghasilkan data yang sama. (Sugiyono, 2016). Pengujian reliabilitas pada penelitian ini menggunakan rumus koefisien reliabilitas Alpha-Cronbach dengan rumus sebagai berikut:

$$
r_{11}=\left[\frac{k}{(k-1)}\right]\left[1-\frac{\sum \sigma_{b^{2}}}{\sigma^{2} t}\right]
$$

Sumber: Morissan dalam (Mahendra, 2016) 
Dasar pengambilan keputusan dalam uji reliabilitas, adalah:

a. Apabila nilai alpha lebih besar daripada nilai $r$ tabel, maka item pertanyaan dinyatakan reliabel.

b. Apabila nilai alpha lebih kecil daripada nilai $r$ tabel, maka item pertanyaan dinyatakan tidak reliabel.

\section{G. Teknik Analisis Dengan Metode Importance Performance Analysis (IPA)}

Pada teknik ini, responden diminta untuk menilai tingkat kepentingan dan tingkat kinerja kemudian nilai rata-rata tingkat kepentingan dan kinerja tersebut dianalisis pada Importance Performance Matrix, yang mana sumbu x mewakili kinerja (persepsi) sedangkan sumbu y mewakili kepentingan (harapan). Grafik IPA dibagi menjadi empat buah kuadran berdasarkan hasil pengukuran importance performance yang memberikan interpretasi.

\section{HASIL DAN PEMBAHASAN}

Penggunaan aplikasi Solfina menjadi sangat penting untuk mendukung proses kegiatan bisnis pekerjaan dalam menghadapi situasi dan kondisi saat ini. Oleh sebab itu aplikasi Solfina dijadikan sebagai ojek penelitian ini yang digunakan oleh karyawan PT. SKK yang menjadi responden. Kuesioner disebarkan ke responden. Setelah kuesioner disebarkan, selanjutnya dilakukan analisis data melalui pengujian validitas dan reliabilitas kemudian datanya dianalisis dengan Importance Performance Analiysis.

\section{A. Deskripsi Data Responden}

Data demografis responden juga diteliti guna mendapatkan gambaran umum sampel yang terlibat dalam penelitian ini.

1. Usia Responden

Berdasarkan usia responden dikategorikan menjadi 3 (tiga) yaitu usia 21 sampai 30 tahun, 31 sampai 40 tahun dan 41 sampai 50 tahun dengan rincian:

Tabel 2.

Data Deskriptif Usia Responden

\begin{tabular}{cccc}
\hline No & Usia Responden & Jumlah & Persentase \\
\hline 1. & 21 sampai 30 tahun & 5 responden & $33 \%$ \\
\hline 2. & 31 sampai 40 tahun & 8 responden & $53 \%$ \\
\hline 3. & 41 sampai 50 tahun & 2 responden & $13 \%$ \\
\hline & Total & 15 responden & $100 \%$ \\
\hline
\end{tabular}

Sumber : Hasil Pengolahan Data (2020)

Dari tabel diatas dapat dilihat usia responden pengguna aplikasi Solfina pada PT. SKK adalah responden dengan usia 21 sampai 30 tahun sebanyak 33\%, sedangkan responden 31 
sampai 40 tahun sebanyak 53\% dan yang berusia 41 sampai 50 tahun sebanyak $13 \%$ dari total responden.

2. Pendidikan Terakhir Responden

Pendidikan terakhir responden dikategorikan dalam 3 (tiga) kategori yaitu Akademi/Diploma, Sarjana (S1) dan Magister (S2/S3). Data deskriptif pendidikan terakhir dari responden dapat dijelaskan pada tabel berikut:

Tabel 3.

Data Deskriptif Pendidikan Terakhir Responden

\begin{tabular}{|c|c|c|c|}
\hline No & Pendidikan Terakhir & Jumlah & Persentase \\
\hline 1 & Akademi/Diploma & 1 responden & $7 \%$ \\
\hline 2 & Sarjana (S1) & 12 responden & $80 \%$ \\
\hline 3 & Magister (S2/S3) & 2 responden & $2 \%$ \\
\hline & Total & 15 responden & $100 \%$ \\
\hline
\end{tabular}

Sumber : Hasil Pengolahan Data (2020)

Tabel diatas menjelaskan pendidikan terakhir dari responden dimana yang Akademi/Diploma sebanyak 7\%, Sarjana (S1) sebanyak 80\% dan responden yang Magister (S2/S3) sebanyak 2\%.

\section{B. Analisis Data}

Dengan memeriksa kembali semua kuesioner yang dikembalikan oleh responden yang kemudian dilakukan tabulasi data yang menghasilkan data yang dibutuhkan guna tujuan analisis variabel-variabel penelitian. Pengujian yang dilakukan yaitu uji validitas dan uji reliabilitas.

1. Uji Validitas

Pada uji validitas ini, dasar pengambilan keputusannya adalah sebagai berikut:

a. Jika nilai rhitung lebih besar dari nilai rtabel, maka angket tersebut dinyatakan valid

b. Jika nilai rhitung lebih kecil dari nilai rtabel, maka angket tersebut dinyatakan tidak valid

Sebelum dilakukan pengujian validitas terlebih dahulu ditentukan taraf nyata $(\alpha)$ yaitu 5\% atau 0,05 dan statistik uji yang digunakan adalah (rho-Spearman), Nilai kritis = nilai tabel dimana $n=15$. $r$ tabel $=r \alpha ;(n-2)=r 0,05 ;(13)=0,560$.

Hasil pengujian persepsi kemudahan penggunaan (perceived ease of use)/X1 tingkat kepentingan (importance): 


\section{Tabel 4.}

Perbandingan Hasil Pengujian r Hitung dengan r Tabel Persepsi Kemudahan Penggunaan (Perceived Ease of Use)/X1 Tingkat Kepentingan (Importance)

\begin{tabular}{cccc}
\hline Variabel & r Hitung & r Tabel & Keputusan \\
\hline $\mathrm{X} 1.1$ & 0,980 & 0,560 & Valid \\
\hline $\mathrm{X} 1.2$ & 0,895 & 0,560 & Valid \\
\hline $\mathrm{X} 1.3$ & 0,980 & 0,560 & Valid \\
\hline $\mathrm{X} 1.4$ & 0,927 & 0,560 & Valid \\
\hline $\mathrm{X} 1.5$ & 0,927 & 0,560 & Valid \\
\hline $\mathrm{X} 1.6$ & 0,980 & 0,560 & Valid \\
\hline
\end{tabular}

Sumber : Hasil Pengolahan Data (2020)

Dari hasil pengujian instrumen penelitian yang diperoleh pada tabel diatas dapat disimpulkan bahwa ke 6 (enam) item pertanyaan dinyatakan valid maka penelitian ini dilanjutkan dan dilakukan juga pengujian validitas persepsi kegunaan (perceived usefulness)/X2 tingkat kepentingan (importance).

\section{Tabel 5.}

Perbandingan Hasil Pengujian r Hitung dengan r Tabel Uji Validitas Persepsi Kegunaan (Perceived Usefulness)/X2 Tingkat Kepentingan (Importance)

\begin{tabular}{cccc}
\hline Variabel & r Hitung & r Tabel & Keputusan \\
\hline $\mathrm{X} 2.1$ & 0,932 & 0,560 & Valid \\
\hline $\mathrm{X} 2.2$ & 0,624 & 0,560 & Valid \\
\hline $\mathrm{X} 2.3$ & 0,923 & 0,560 & Valid \\
\hline $\mathrm{X} 2.4$ & 0,932 & 0,560 & Valid \\
\hline $\mathrm{X} 2.5$ & 0,932 & 0,560 & Valid \\
\hline $\mathrm{X} 2.6$ & 0,923 & 0,560 & Valid \\
\hline
\end{tabular}

Sumber : Hasil Pengolahan Data (2020)

Dari hasil pengujian instrumen penelitian yang diperoleh pada tabel diatas dapat disimpulkan bahwa ke 6 (enam) item pertanyaan dinyatakan valid maka penelitian ini dan dilakukan juga pengujian validitas persepsi kemudahan penggunaan (perceived ease of use)/Y1 tingkat kinerja (performance).

\section{Tabel 6.}

Perbandingan Hasil Pengujian r Hitung dengan r Tabel Persepsi Kemudahan Penggunaan (Perceived Ease of Use)/ Y1 Tingkat Kinerja (Performance)

\begin{tabular}{cccc}
\hline Variabel & r Hitung & r Tabel & Keputusan \\
\hline Y1.1 & 0,835 & 0,560 & Valid \\
\hline Y1.2 & 0,849 & 0,560 & Valid \\
\hline Y1.3 & 0,930 & 0,560 & Valid \\
\hline Y1.4 & 0,663 & 0,560 & Valid \\
\hline Y1.5 & 0,590 & 0,560 & Valid \\
\hline Y1.6 & 0,906 & 0,560 & Valid \\
\hline
\end{tabular}

Sumber : Hasil Pengolahan Data (2020) 
Dari hasil pengujian instrumen penelitian yang diperoleh pada tabel diatas dapat disimpulkan bahwa ke 6 (enam) item pertanyaan dinyatakan valid maka penelitian ini dilanjutkan dan dilakukan juga pengujian validitas persepsi kegunaan (perceived usefulness)/Y2 tingkat kinerja (performance).

\section{Tabel 7.}

Perbandingan Hasil Pengujian r Hitung dengan r Tabel Uji Validitas Persepsi Kegunaan (Perceived Usefulness)/ Y2 Tingkat Kinerja (Performance)

\begin{tabular}{cccc}
\hline Variabel & r Hitung & r Tabel & Keputusan \\
\hline $\mathrm{X} 2.1$ & 0,915 & 0,560 & Valid \\
\hline $\mathrm{X} 2.2$ & 0,972 & 0,560 & Valid \\
\hline $\mathrm{X} 2.3$ & 0,981 & 0,560 & Valid \\
\hline $\mathrm{X} 2.4$ & 0,930 & 0,560 & Valid \\
\hline $\mathrm{X} 2.5$ & 0,930 & 0,560 & Valid \\
\hline $\mathrm{X} 2.6$ & 0,889 & 0,560 & Valid
\end{tabular}

Sumber : Hasil Pengolahan Data (2020)

Berdasarkan hasil uji coba instrumen penelitian diperoleh dari tabel diatas dapat disimpulkan bahwa ke 6 (enam) item pertanyaan dinyatakan valid maka penelitian ini dilanjutkan dengan uji reliabilitas.

2. Uji Reliabilitas

Saat ini SPSS memberikan fasilitas untuk mengukur reliabilitas dengan uji statistik Cronbach Alpha. Dasar pengambilan keputusan uji reliabilitas adalah Jika Nilai Croanbach's Alpha > 0.60 maka kuesioner atau angket dinyatakan reliabel atau konsisten. Jika Nilai Croanbach's Alpha $<0.60$ maka kuesioner atau angket dinyatakan tidak reliabel atau tidak konsisten. Hasil pengujian dapat dibandingkan dalam tabel dibawah ini:

Tabel 8.

Perbandingan Hasil Pengujian Reliabilitas Masing-Masing Variabel

\begin{tabular}{|c|c|c|c|}
\hline Variabel & $\begin{array}{l}\text { Nilai } \\
\text { Croanbach's } \\
\text { Alpha }\end{array}$ & r Tabel & Keterangan \\
\hline $\begin{array}{c}\text { Hasil Uji Reabillitas Variabel Persepsi Kemudahan } \\
\text { Penggunaan (Perceived Ease of Use)/X1 Tingkat } \\
\text { Kepentingan (Importance) }\end{array}$ & 0,977 & 0,60 & Reliable \\
\hline $\begin{array}{c}\text { Hasil Uji Reabillitas Variabel Persepsi Kegunaan } \\
\text { (Perceived Usefulness)/X2 Tingkat Kepentingan } \\
\text { (Importance) }\end{array}$ & 0,931 & 0,60 & Reliable \\
\hline $\begin{array}{c}\text { Hasil Uji Reabillitas Variabel Persepsi Kemudahan } \\
\text { Penggunaan (Perceived Ease of Use)/Y1 Tingkat Kinerja } \\
\text { (Performance) }\end{array}$ & 0,885 & 0,60 & Reliable \\
\hline $\begin{array}{c}\text { Hasil Uji Reabillitas Variabel Persepsi Kegunaan } \\
\text { (Perceived Usefulness)/Y2 Tingkat Kinerja } \\
\text { (Performance) }\end{array}$ & 0,954 & 0,60 & Reliable \\
\hline
\end{tabular}

Sumber : Hasil Pengolahan Data (2019)

Dari tabel diatas diketahui nilai alpha untuk uji reabillitas variabel persepsi kemudahan penggunaan (perceived ease of use)/X1 tingkat kepentingan (importance) sebesar 0,977, 
nilai alpha untuk uji reabillitas variabel persepsi kegunaan (perceived usefulness)/X2 tingkat kepentingan (importance) sebesar 0,931, nilai alpha untuk uji reabillitas variabel persepsi kemudahan penggunaan (perceived ease of use)/Y1 tingkat Kinerja (performance) sebesar 0,885 dan nilai alpha untuk uji reabillitas variabel persepsi kegunaan (perceived usefulness)/Y2 tingkat kinerja (performance) sebesar 0,954. Keseluruhan variabel menunjukkan nilai yang lebih besar dari $\mathrm{r}$ tabel yaitu sebesar 0,60 sehingga seluruh variabel adalah reliable.

3. Analisis Data Dengan Importance Performance Analysis (IPA)

Setelah dilakukan uji validitas dan reliabilitas instrumen penelitian dan diperoleh bahwa instrumen telah valid dan reliabel maka selanjutnya dianalisa gap antara tingkat kepentingan (importance) dan tingkat kinerja (performance) pengguna terhadap kualitas aplikasi Solfina yang ada saat ini yang ditunjukkan sebagai berikut:

Tabel 9.

Analisa Gap Tingkat Kepentingan (Importance) dan Tingkat Kinerja (Performance) Pengguna

\begin{tabular}{|c|c|c|c|c|}
\hline $\mathrm{No}$ & Variabel Yang di Ukur & $\begin{array}{c}\text { Tingkat Kepentingan } \\
\text { (Importance) }\end{array}$ & $\begin{array}{l}\text { Tingkat Kinerja } \\
\text { (Performance) }\end{array}$ & $\begin{array}{c}\text { Skor } \\
\text { Kepuasan }\end{array}$ \\
\hline \multicolumn{5}{|c|}{ Persepsi Kemudahan Penggunaan (Perceived Ease of Use) } \\
\hline 1. & Aplikasi Solfina mudah dipelajari. & 4,6667 & 4,3333 & $-0,3333$ \\
\hline 2. & Aplikasi Solfina mudah dikendalikan. & 4,6000 & 4,1333 & $-0,4667$ \\
\hline 3. & Aplikasi Solfina jelas dan mudah dipahami. & 4,6667 & 4,4000 & $-0,2667$ \\
\hline 4. & Aplikasi Solfina fleksibel. & 4,7333 & 4,1333 & $-0,6000$ \\
\hline 5. & $\begin{array}{l}\text { Mudah untuk terampil dalam menggunakan } \\
\text { aplikasi Solfina. }\end{array}$ & 4,7333 & 4,4667 & $-0,2667$ \\
\hline 6. & Aplikasi Solfina mudah diakses. & 4,6667 & 4,3333 & $-0,3333$ \\
\hline \multicolumn{5}{|c|}{ Persepsi Kegunaan (Perceived Usefulness) } \\
\hline 7. & $\begin{array}{l}\text { Menggunakan aplikasi Solfina membuat } \\
\text { pekerjaan lebih cepat. }\end{array}$ & 4,8000 & 4,6000 & $-0,2000$ \\
\hline 8. & 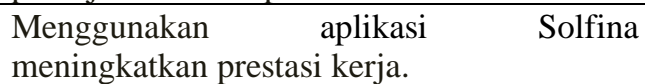 & 4,6667 & 4,4000 & $-0,2667$ \\
\hline 9. & $\begin{array}{l}\text { Menggunakan aplikasi } \\
\text { meningkatkan produktivitas. }\end{array}$ & 4,8667 & 4,2667 & $-0,6000$ \\
\hline 10. & $\begin{array}{l}\text { Menggunakan aplikasi } \\
\text { meningkatkan efektivitas. }\end{array}$ & 4,8000 & 4,5333 & $-0,2667$ \\
\hline 11. & $\begin{array}{l}\text { Menggunakan aplikasi Solfina membuat } \\
\text { pekerjaan menjadi lebih mudah. }\end{array}$ & 4,8000 & 4,5333 & $-0,2667$ \\
\hline 12. & Aplikasi Solfina berguna dalam bekerja. & 4,8667 & 4,4667 & $-0,4000$ \\
\hline
\end{tabular}

Sumber : Hasil Pengolahan Data (2020)

Pada tabel dapat dilihat bahwa pada kolom Tingkat Kinerja (Performance) umumnya lebih rendah dari kolom Tingkat Kepentingan (Importance), dengan demikian untuk kolom skor kepuasan menggunakan rumus Tingkat Kinerja (Performance) - Tingkat Kepentingan (Importance $)=$ Skor Kepuasan. Penerapan rumus tesebut diterapkan pada kolom skor kepuasan dan dapat dilihat bahwa nilai pada kolom tersebut bernilai negatif, dengan pemahaman bahwa pada semua variable diuji pada responden belum memenuhi harapan 
responden. Dengan kata lain dapat dikatakan secara umum pengguna belum merasa puas terhadap aplikasi Solfina yang ada saat ini.

Untuk mengetahui skala prioritas perbaikan terhadap aplikasi Solfina dilakukan analisis lanjutan dengan alat bantu IPA (Importance Performance Analysis) dimana item yang ada dipetakan ke dalam grafik IPA yang terbagi menjadi empat kuadran sebagai berikut:

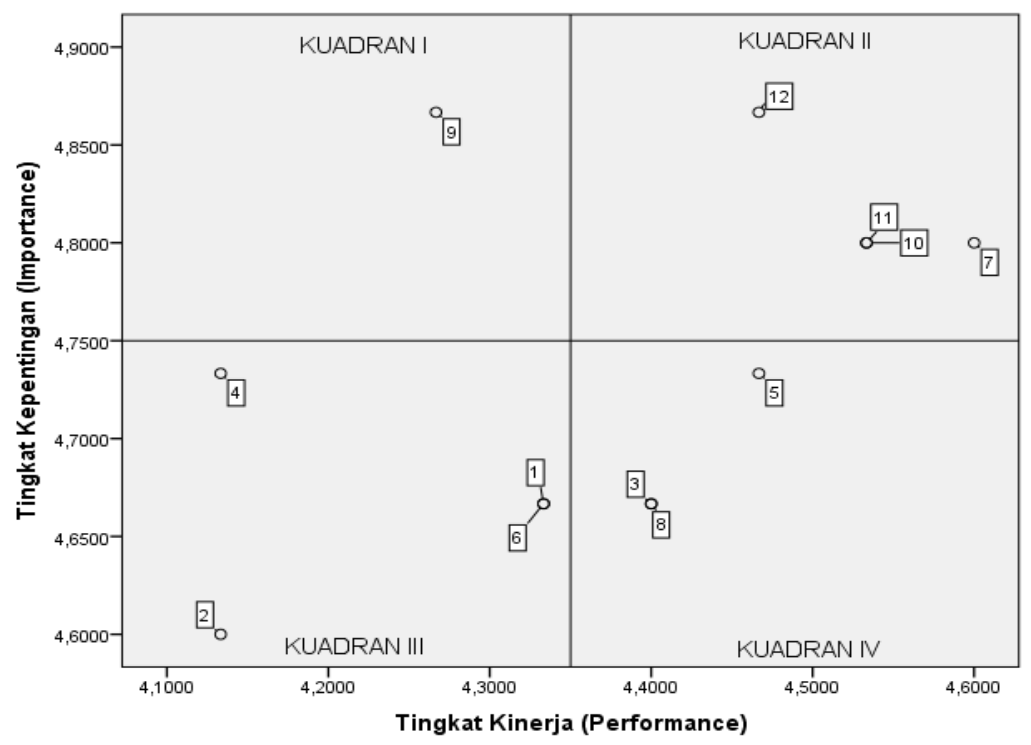

Gambar 4. Grafik IPA Hasil Pemetaan

Berdasarkan gambar 4 di atas dapat dilihat bahwa seluruh item telah dipetakan ke dalam empat kuadran dengan skala prioritas:

a. Kuadran I

Item yang termasuk dalam kuadran ini merupakan prioritas utama peningkatan kualitas aplikasi Solfina yakni terdiri dari:

[9] Menggunakan aplikasi Solfina meningkatkan produktivitas.

Item di atas ini termasuk area yang penting menurut persepsi pengguna namun belum memenuhi harapan/ekspektasi pengguna sehingga perlu segera diperbaiki agar sesuai dengan harapan pengguna.

b. Kuadran II

Item yang termasuk dalam kuadran ini merupakan prestasi atau keunggulan aplikasi Solfina yang harus dipertahankan karena telah memenuhi harapan pengguna yaitu :

[7] Menggunakan aplikasi Solfina membuat pekerjaan lebih cepat.

[10] Menggunakan aplikasi Solfina meningkatkan efektivitas.

[11] Menggunakan aplikasi Solfina membuat pekerjaan menjadi lebih mudah.

[12] Aplikasi Solfina berguna dalam bekerja. 
Keempat item di atas adalah area yang penting menurut persepsi pengguna dan dianggap telah memenuhi ekspektasi pengguna.

c. Kuadran III

Item yang termasuk dalam kuadran ini merupakan skala prioritas yang rendah bagi pengelola aplikasi Solfina karena tidak dianggap penting oleh pengguna yaitu :

[1] Aplikasi Solfina mudah dipelajari.

[2] Aplikasi Solfina mudah dikendalikan.

[4] Aplikasi Solfina fleksibel.

[6] Aplikasi Solfina mudah diakses.

Ke empat item di atas merupakan area yang dianggap tidak penting oleh pengguna sehingga prioritasnya rendah dan dapat diabaikan oleh pengelola.

d. Kuadran IV

Item yang termasuk dalam kuadran ini merupakan area yang dianggap berlebihan karena tidak dianggap penting oleh pengguna namun persepsi/kinerjanya tinggi. Dalam hal ini perlu dialihkan sumber dayanya kepada skala prioritas yang lebih tinggi yakni kuadran I atau kuadran II yaitu:

[3] Aplikasi Solfina jelas dan mudah dipahami.

[5] Mudah untuk terampil dalam menggunakan aplikasi Solfina.

[8] Menggunakan aplikasi Solfina meningkatkan prestasi kerja.

\section{KESIMPULAN DAN REKOMENDASI}

Berdasarkan hasil penelitian dan pembahasan dapat diambil kesimpulan, sebagai berikut :

1. Hasil uji validitas instrumen penelitian yang diperoleh dapat disimpulkan bahwa keseluruhan item pertanyaan dinyatakan valid maka penelitian ini dilanjutkan.

2. Nilai alpha uji reabillitas pada keseluruhan variabel menunjukkan nilai yang lebih besar dari $r$ tabel sehingga seluruh variabel adalah reliabel.

3. Berdasarkan analisis gap ditemukan bahwa secara umum pengguna aplikasi Solfina belum merasa puas terhadap kegunaan dan kemudahan aplikasi Solfina.

4. Berdasarkan analisis IPA dapat dipetakan skala prioritas peningkatan kualitas aplikasi Solfina dimana kuadran I adalah skala prioritas tertinggi menurut perspektif pengguna adalah [9], item ini harus segera ditingkatkan oleh pengelola untuk memenuhi harapan pengguna. 
5. Area yang menjadi prestasi atau keunggulan aplikasi Solfina yang harus dipertahankan terletak pada kuadran II yaitu: [7], [10], [11] dan [12].

6. Yang merupakan skala prioritas yang rendah bagi pengelola karena tidak dianggap penting oleh pengguna yaitu [1], [2], [4] dan [6].

7. Area yang dianggap berlebihan karena tidak dianggap penting oleh pengguna namun persepsi/kinerjanya tinggi. Dalam hal ini perlu dialihkan sumber dayanya kepada skala prioritas yang lebih tinggi yakni kuadran I atau kuadran II yaitu: [3], [5] dan [8].

8. Dari penjelasan diatas dapat disimpulkan secara umum aplikasi Solfina harus diperbaiki ini menunjukkan bahwa hipotesa $\mathrm{H} 0$ diterima dan $\mathrm{H} 1$ ditolak.

Harapan kedepannya aplikasi Solfina tetap harus dikembangkan lagi terutama untuk kuadran I dengan skala prioritas tertinggi menurut perspektif pengguna yaitu item [9]. Jika dilakukan lagi penelitian yang mambahas aplikasi ini diharapkan responden ditingkatkan dan dibuat penelitian dengan model atau metode yang berbeda agar hasilnya dapat dibandingkan dengan hasil penelitian ini.

\section{REFERENSI}

Abdurahman, Hasan \& Riswaya, A. Ri. (2014). Aplikasi Pinjaman Pembayaran Secara Kredit Pada Bank Yudha Bhakti. Jurnal Computech \& Bisnis, Vol 8(No 2), 61-69.

Agustina, N., \& Sutinah, E. (2019). Model Delone dan McLean Untuk Menguji Kesuksesan Aplikasi Mobile Penerimaan Mahasiswa Baru. Jurnal Nasional Informatika Dan Teknologi Jaringan, 3(2), 76-82.

Fatmawati, E. (2015). Technology Acceptance Model (TAM) Untuk Menganalisis Penerimaan Terhadap Siste Informasi Perpustakaan. Jurnal Iqra', 09(01), 1-13.

Lubis, B. O., \& Salim, A. (2016). Aplikasi Android Untuk Menentukan Jarak Terpendek Antar Terminal Di Jakarta. In SENSITif 2016 (pp. 87-100). Retrieved from https://repository.bsi.ac.id/index.php/repo/viewitem/741

Lubis, B. O., Santoso, B., Aji, A. M. B., Haidir, A., \& Salim, A. (2019). Analisis Penggunaan Aplikasi LOS Terhadap Percepatan Aproval Kredit. Journal Speed Sentra Penelitian Engineering Dan Edukasi, 11(3), 6-13. Retrieved from speed.web.id

Mahendra, I. (2016). Penggunaan Technology Acceptance Model (TAM) Dalam Mengevaluasi Penerimaan Pengguna Terhadap Sistem Informasi Pada PT . Ari Jakarta. Sistem Informasi STMIK Antar Bangsa, 5(2), 183-195.

Nurfiyah, N., Mayangky, N. A., Hadianti, S., \& Riana, D. (2019). Analisis Technology http://journal.thamrin.ac.id/index.php/jtik/issue/view/40 


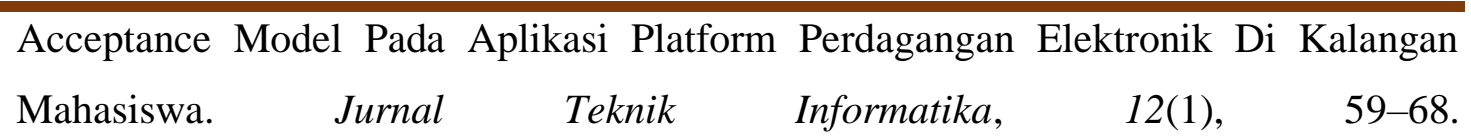
https://doi.org/10.15408/jti.v12i1.10507

Siregar, H. F., Siregar, Y. H., \& Melani, M. (2018). Perancangan Aplikasi Komik Hadist Berbasis Multimedia. Jurnal Teknologi Informasi, 2(2), 113. https://doi.org/10.36294/jurti.v2i2.425

Solsistem, P. S. (2021). BEST INDONESIA PAYROLL \& PPh 21 SOFTWARE. Retrieved from http://solfina.id/hris/About.aspx

Sugiarto. (2017). Metodologi Penelitian Bisnis. Yogyakarta: Andi.

Sugiyono. (2016). Metode Penelitian Kuantitatif, Kualitatif, dan R\&D. Bandung: Alfabeta. Widianto, K. (2015). Kajian Penggunaan Software Zahir Accounting Dengan Pendekatan Technology Acceptance Model (Studi Kasus: Mahasiswa Program Studi Komputerisasi Akuntansi AMIK “BSI Bogor”). Khatulistiwa Informarmatika, 3(1), $37-47$. 